\title{
Effects of Gender Pre-Retirement Preparation and Adjustment In Retirement: A Case Study Of Enugu State, Nigeria
}

\author{
Dr. A.U. Anibueze \\ General Studies Unit Federal University Oye-Ekiti, Ekiti State, Nigeria
}

\begin{abstract}
This study was designed to investigate the effects of gender preparation and adjustment in retirement of retired civil servants in Enugu State, Nigeria. To guide the study, five (5) research questions were administered and three hypotheses tested. The population of the study consisted of the retired civil servants in Enugu State numbering about 828. Out of that number, 331were sampled using stratified approach. An instrument named Gender Preparation and Adjustment to Retirement Scale was designed by the researcher and validated by experts. The reliability of the instrument was established using trial testing of 50 retired civil servants in Ebony State. The data collected were analyzed using the Pearson Product Moment Correlation Coefficient, mean standard deviation, $t$-test of $r$ and t-test statistics. The hypotheses were tested at 0.05 level of significant. The result of the study revealed that there was lack of awareness and poor preparation to retirement, that there is maladjustment or poor adjustment to retirement by retirees in Enugu State. There is no gender difference in preparation to retirement and that there is a significant though negative relationship at 050 between preparation and adjustment to retirement. Based on the findings, recommendations were made.
\end{abstract}

Keywords: Adjustment, Gender, Influence, Preparation, Retirement

\section{Introduction}

The individual who is going into retirement from active service is entering a new phase of life, which like every new stage will have its own peculiar conditions. Such a person is going into life unknown. Quite often, the uncertainties of life make people apprehensive of the future. It is not unlikely, therefore that the individual who is about to retire will be apprehensive of the approaching new phase of life, life after retirement. After retirement, retirees face lots of problems because there is among other things perceived reduction in their income by one- fort of their former income. Abudu (1985) reported that there is a significant decrease in the purchasing power of retirees as compared to the pre-retirement purchasing power. Inability to function optimally is a common feature of most retirees and it usually gives rise to somatic stress. Igwebueze (1988) presented a retiree view that people often approach retirement with fear because of the hardship that comes with it. Pension is always small and prices keep jumping higher and higher.

Another possible answer to the cause of fear and anxiety is that the public servant is not sure whether his employers will fulfill their own part of the terms of employment with respect to the payment of entitlement such as gratuity and life pension. The public servant is also not sure that when he is gone, there will be a fruitful backward linkage between him and his former employer. Osuala (1985) discovered that immediately one gets involuntarily retired, loneliness sets in, the retiree finds it difficult to stay without another person, he begins to know and realize the position of his erstwhile jobs in his life. According to a survey, some retirees reported that they missed something about working, usually the income and their friends at work.

According to Uzoma (1998) boredom with oneself and others, no real satisfaction from leisure activities, all dressed and nowhere to go, all dressed up somewhere to go but no one to go with, friction with spouse when time increases, not enough thing to do, hard time deciding what to do, bankroll of a peasant but tastes of a millionaire.

Retirement which ought to be an achievement and honor to those who are fortunate to merit it as in some cases turned out to be a thing of regret and cause of misery. Gioieua and Bevil (1985) said that the retired people encounter gloomy portraits of boredom and meaninglessness; a large body of studies suggests that retirement constitute severe crises especially as work is viewed as the central life task.

In a study conducted by Abdulrazag (1999) at Kwara state, the available data show that there are five major problem areas of facing retired civil servants in the state, these areas are presented in there order of seriousness; financial problem $91 \%$, health problem $78 \%$, social problem $78 \%$, retirement shock problem $77 \%$ and psychological problems 70\%. Uzoma (1998) discovered that for many executives and even for people running their own business the thought of giving up work at all, comes as a shock, the shock is largely due to lack of preparation. To the unprepared, having a great deal of spare time on retirement can bring on many anxieties. Hurlock (1968) stressed that retirement shock is the new sickness of the aged, because far too few 
elderly people are prepared, either through choice or through conditions beyond their control for retirement. Retirement shock is becoming one of the major problems of the elderly in the world today.

Gee (2002) on Savings Ourselves: Gender Issues in Making Provision on One's Own Retirement; discovered that, overall, women were less likely to save for their own retirement than were men; however, this gender difference was no longer significant when income was taken into consideration. Those less likely to be making provision for their own retirement included individuals with poor health and lower income and women who had divorced or who provided care. The relative economic position and social roles of women may engender vulnerability to economic dependence in later life.

Another factor, which is known to influence preparation to retirement is psychological factor, Olagboye (1998) observed that the existing body of knowledge developed through both laboratory and organizational research indicate that perception is influenced by many factors; such as need values, cultural background, age, sex, educational attainment and experience among others. It is clear that no two individual can perceive the same stimuli in exactly the same way. For example, while one worker may perceive his retirement from work as humiliating blow to his self-esteem, another may perceive it as a challenge. The two individuals may experience stress but to different degrees and dimensions. Women whose natural role is domestic appear to be cozier at preparation and adjustment in retirement than their male counterparts.

There is enough evidence that a good number of retired civil servants are suffering in this country. Reports from our dailies and scholarly works portray a gloomy picture of retirees in the state of abject poverty. Most retirees manifest maladjustment in various forms. Some even beg in the streets. Some even die for lack of what to eat. Many are uncertain about tomorrow. Worse is that there appear to be gender imbalance among retirees maladjustment. Women show matured posture in adjustment to retirement when compared to men.

Following from these absurd manifestations, the young working population in civil service is no more eager to reach their retirement age as a result of these crises that can ensure. Those who brave to work till retirement age indulge in one corrupt practice or the order. The worry of this research therefore is; whether there is gender difference in preparation and adjustment to retirement, whether retired civil servants who are suffering today ever thought of or prepared for what they are witnessing today.

However, not much has been empirically reported on the various problems emanating from the preretirement preparation and post-retirement adjustment of gender in Nigeria, thus these recent developments of retirement crises among gender makes researches in this area important in Enugu State, Nigeria. This research is of immense value since it answered the burning questions related to gender differences in preparation and adjustment in retirement.

Nonetheless, the findings in this study will hopefully help in educating counselors, civil servants, women and men on the pitfalls associated with preparation to and adjustment in retirement. Based on the statement of the problem and purpose of study, the following research questions were examined; what is the influence of gender on preparation for retirement?, what is the influence of gender on adjustment to retirement?, what is the mean rating of retirees on the extent of preparation towards retirement as measure by retirement preparation rating scale?, what is the mean rating of retirees on the extent of adjustment as measured by retirement adjustment rating scale?, what is the relationship between retiree's preparation and adjustment on retirement? Three hypotheses were tested at 0.05 level of significant; there is no difference in the mean rating of retirees on pre-retirement preparation due to gender, there is no significant difference of in the mean rating of retirees on their post retirement adjustment due to gender

\section{Methods}

This study adopted an Ex Post Facto design, this is because this study is designed to study already existing retired civil servants to know how they prepared for retirement and how they adjusted or are adjusting in retirement. The area of the study is Enugu State in Nigeria, with 17 local government areas. The population of the study consists of all the retired civil servants in the state. Records from the Ministry of Finance Enugu State show that there are 828 registered retired civil servants receiving their pension at Enugu State sub-treasuries spread across the state in 2011.

Using simple random and stratified sampling approach, $40 \%$ (331) of the retired civil servants were selected. 64 females' retirees were available for the study, making $19 \%$, while 267 males representing $81 \%$ of the study population. The instrument for data collection is the researchers developed questionnaire titled "The relationship between pre-retirement preparation and post-retirement adjustment of retired civil servants questionnaire". The questionnaire consist of three major sections that provided answers to; age, sex, establishment, type of retirement, highest educational qualification, rank at retirement, information on retirement preparation and post-retirement adjustment.

The instrument was face validated by 5 experts from the Faculty of Education University of Nigeria Nsukka. The reliability of the instrument was carried out by the researcher through the conduct of trial testing of 50 retired civil servants in a neighboring state Ebonyi state. Using Crombach Alpha the reliability of the 
instrument was computed with a score of 0.82 which deemed the instrument reliable. The data collection was conducted by the researcher and two research assistants through direct delivery method. This method was chosen to ensure a high and prompt completion and return of the questionnaire. In analyzing the data, four-point Likert-type scale was used to rate the responses of the items of the questionnaire. The researcher employed the weights attached to the scale to compute the mean scores of the items of the questionnaire. The level of acceptance of each item of the questionnaire was a mean score 2.50 and above on the four point rating scale. For research question 1, 2, 4 and 5, the mean and standard deviation was used. Pearson Product Moment Correlation Coefficient was employed for research question 3. Hypotheses 1 was tested with t-test of R, while hypotheses 2 and 3 was tested with t-test at 0.05 level of significant.

Table 1: Summary of item mean and standard deviation scores on preparation for retirement.

\begin{tabular}{|c|c|c|c|c|c|c|c|}
\hline Items & VGE & GE & LE & VLE & Mean & SD & Decision \\
\hline Brought shares & 39 & 42 & 72 & 164 & 1.82 & 1.09 & Low \\
\hline Bought bonds & 10 & 16 & 52 & 231 & 1.28 & 0.78 & Low \\
\hline $\begin{array}{ll}\text { Trained your } \\
\text { children }\end{array}$ & 123 & 114 & 49 & 41 & 2.94 & i. 06 & High \\
\hline Built houses & 71 & 69 & 71 & 103 & 2.22 & 1.24 & Low \\
\hline $\begin{array}{ll}\begin{array}{l}\text { Learnt } \\
\text { skills }\end{array} & \text { some } \\
\end{array}$ & 34 & 77 & 90 & 113 & 1.99 & 1.09 & Low \\
\hline $\begin{array}{l}\text { Saved enough } \\
\text { money }\end{array}$ & 148 & 92 & 59 & 19 & 1.77 & 0.98 & Low \\
\hline $\begin{array}{l}\text { Maintained } \\
\text { some private } \\
\text { business } \\
\text { ventures }\end{array}$ & 23 & 41 & 79 & 170 & 1.64 & 1.00 & Low \\
\hline $\begin{array}{lr}\text { Secured } & \text { a } \\
\text { large area of } \\
\text { land for } \\
\text { farming }\end{array}$ & 90 & 49 & 63 & 115 & 2.26 & 1.3 & Low \\
\hline $\begin{array}{l}\text { Went to the } \\
\text { counselor for } \\
\text { training }\end{array}$ & 10 & 23 & 92 & 183 & 1.44 & 0.84 & Low \\
\hline $\begin{array}{l}\text { Attended } \\
\text { seminar and } \\
\text { conferences }\end{array}$ & 21 & 50 & 101 & 140 & 1.74 & 0.99 & Low \\
\hline $\begin{array}{l}\text { Read up so } \\
\text { many books } \\
\text { about } \\
\text { retirement }\end{array}$ & 24 & 49 & 98 & 139 & 1.75 & 1.03 & Low \\
\hline $\begin{array}{l}\text { Attended } \\
\text { workshops on } \\
\text { retirement }\end{array}$ & 23 & 35 & 72 & 177 & 1.57 & 1.01 & Low \\
\hline $\begin{array}{l}\text { Participated in } \\
\text { some training }\end{array}$ & 23 & 46 & 70 & 165 & 1.71 & 1.97 & Low \\
\hline $\begin{array}{l}\text { Felt the } \\
\text { government } \\
\text { will take care } \\
\text { of you }\end{array}$ & 146 & 66 & 51 & 60 & 2.85 & 1.23 & High \\
\hline $\begin{array}{l}\text { Felt your } \\
\text { pension will } \\
\text { take care of } \\
\text { your financial } \\
\text { needs }\end{array}$ & 98 & 89 & 73 & 63 & 2.62 & 1.16 & High \\
\hline $\begin{array}{l}\text { Felt your } \\
\text { children will } \\
\text { take care of } \\
\text { you }\end{array}$ & 96 & 127 & 45 & 58 & 2.76 & 1.09 & High \\
\hline 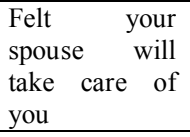 & 25 & 102 & 82 & 111 & 2.06 & 1.04 & Low \\
\hline $\begin{array}{l}\text { Did some } \\
\text { voluntary } \\
\text { work } \\
\end{array}$ & 44 & 84 & 102 & 80 & 2.15 & 1.12 & Low \\
\hline $\begin{array}{l}\text { Maintained } \\
\text { good relation } \\
\text { with friends }\end{array}$ & 133 & 140 & 38 & 17 & 3.16 & 0.88 & Low \\
\hline $\begin{array}{l}\text { Engaged } \\
\text { yourself in a } \\
\text { lot of social }\end{array}$ & 40 & 90 & 22 & 72 & 2.25 & 0.99 & Low \\
\hline
\end{tabular}




\begin{tabular}{|c|c|c|c|c|c|c|c|}
\hline work & & & & & & & \\
\hline $\begin{array}{l}\text { Trained } \\
\text { yourself } \\
\text { against } \\
\text { competition }\end{array}$ & 34 & 93 & 76 & 117 & 2.07 & 1.09 & Low \\
\hline $\begin{array}{l}\text { Trained } \\
\text { yourself } \\
\text { help others }\end{array}$ & 121 & 93 & 79 & 35 & 2.89 & 1.05 & High \\
\hline 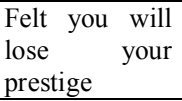 & 40 & 49 & 66 & 161 & 1.81 & 1.13 & Low \\
\hline 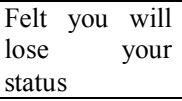 & 25 & 47 & 73 & 172 & 1.69 & 1.02 & Low \\
\hline $\begin{array}{l}\text { Felt you did } \\
\text { not achieve } \\
\text { much } \\
\text { preparing for } \\
\text { retirement }\end{array}$ & 45 & 63 & 107 & 108 & 1.18 & 1.96 & Low \\
\hline $\begin{array}{l}\text { Took some } \\
\text { titles in your } \\
\text { community }\end{array}$ & 23 & 31 & 61 & 188 & 1.49 & 1.01 & Low \\
\hline $\begin{array}{l}\text { Prepared } \\
\text { yourself } \\
\text { against lost of } \\
\text { confidence }\end{array}$ & 63 & 99 & 98 & 67 & 2.52 & 1.50 & High \\
\hline $\begin{array}{l}\text { Prepared } \\
\text { yourself for } \\
\text { leadership } \\
\text { positions }\end{array}$ & 54 & 88 & 92 & 85 & 2.26 & 1.12 & Low \\
\hline $\begin{array}{l}\text { Participated in } \\
\text { development } \\
\text { projects. }\end{array}$ & 65 & 99 & 58 & 99 & 2.33 & 1.18 & Low \\
\hline Grand mean & & & & & 2.032 & & Low \\
\hline
\end{tabular}

On a general note, the grand mean of 2.032 indicates that retirees were not prepared for retirement before they got retired. Judging from the three dimensions of preparatory scale; financial, psychological and social preparation, items 3 with 2.94 score indicate that the major financial preparation towards retirement is training of children. The major psychological preparation is that the retirees felt the government will take care of them with 2.58, felt that pension will take care of their financial needs with 2.62 score and felt their children will take care of them with 2.76 score. While social preparation indicate that retirees trained themselves to help others with 2.89 and prepared themselves against lost of confidence with 2.52 score. Other items as shown in the table scored below the margin of 2.50 acceptance level, meaning that they were not considered important for retirement.

Table 2: Summary of item mean and standard deviation scores on adjustment to retirement.

\begin{tabular}{|l|l|l|l|l|l|l|l|}
\hline Item & VGE & GE & LE & VLE & Mean & SD & Decision \\
\hline $\begin{array}{l}\text { I feel disturbed } \\
\text { that I cannot } \\
\text { meet up with my } \\
\text { financial } \\
\text { obligations (now } \\
\text { in retirement }\end{array}$ & 101 & 57 & 81 & 81 & 2.34 & 1.26 & Low \\
\hline $\begin{array}{l}\text { I regret my } \\
\text { condition now } \\
\text { because I feel I } \\
\text { did not prepare } \\
\text { well financially. }\end{array}$ & 61 & 51 & 90 & 112 & 1.199 & 1.184 & Low \\
\hline $\begin{array}{l}\text { My complaint in } \\
\text { retirement is non } \\
\text { payment } \\
\text { retirement } \\
\text { benefits }\end{array}$ & 98 & 57 & 85 & 86 & 2.53 & 1.22 & High \\
\hline $\begin{array}{l}\text { I regret my } \\
\text { financial } \\
\text { abandonment by } \\
\text { members of my } \\
\text { family }\end{array}$ & 42 & 30 & 91 & 146 & 1.70 & 1.09 & Low \\
\hline $\begin{array}{l}\text { You do not seem } \\
\text { stressed up }\end{array}$ & 47 & & & & & & \\
\hline Your health & 47 & 65 & 103 & 101 & 2.00 & 1.09 & Low \\
\hline
\end{tabular}




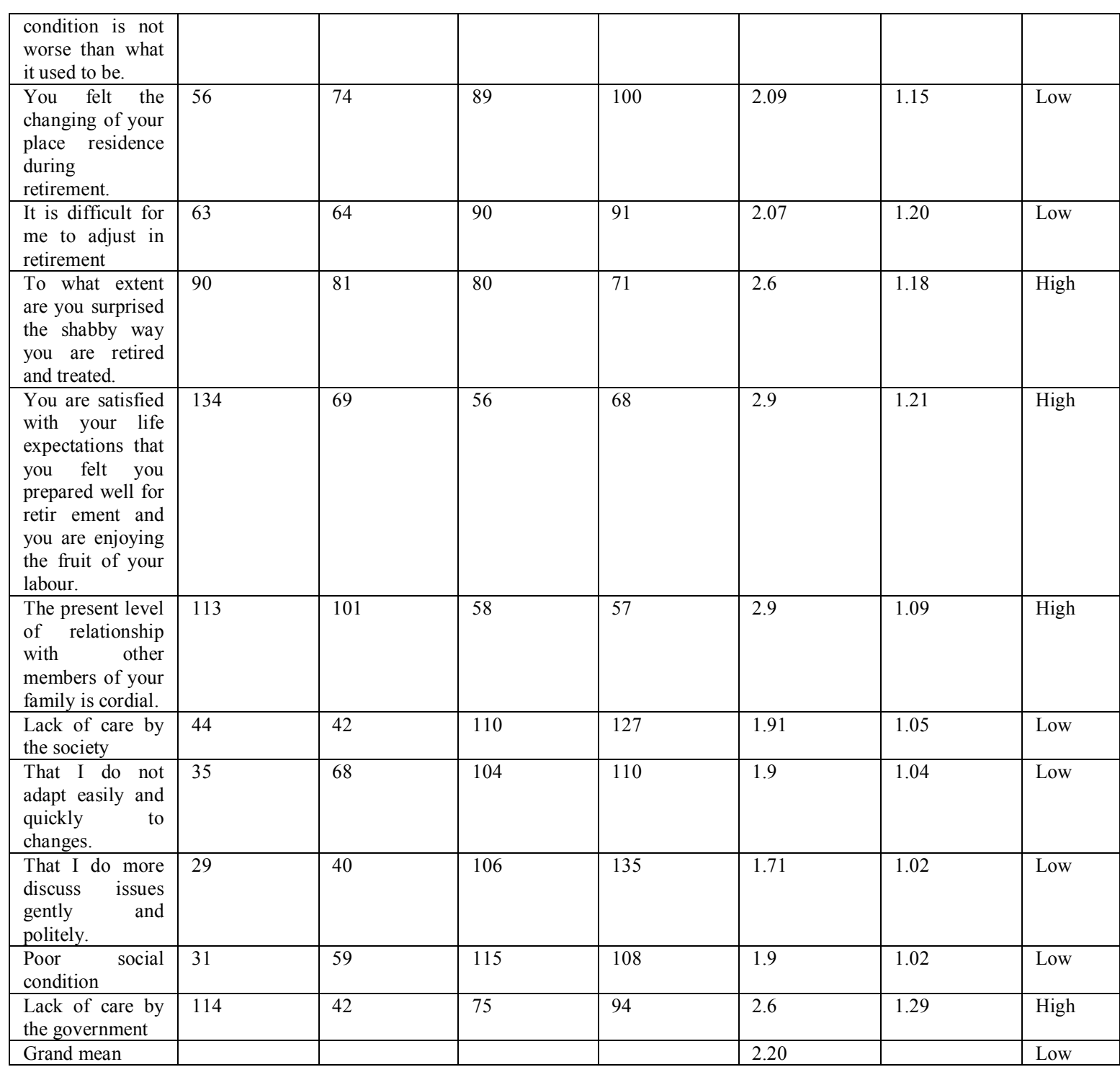

The grand mean of 2.20 is less than 2.50 benchmark, therefore the retirees are adjusted. Judging from the three categories of our study; financial, psychological, and social, items 3 show that retirees perceive non-payment of their retirement benefits as most disturbing. Items 9 and 11 with 2.6 and 2.9 respectively showed that retirees are deeply surprised the shabby way they were retired and treated. Yet their present level of relationship with family members is still cordial. Above all, the retirees felt bad the lack of care from the government the spent their entire working.

Table 3: Pearson's correlation matrix for preparation and adjustment in retirement.

\begin{tabular}{|l|l|l|l|}
\hline & Preparation & Adjustment & Decision \\
\hline Preparation & 1.000 & -.050 & Negative \\
\hline Adjustment & -.050 & 1.000 & Negative \\
\hline
\end{tabular}

This table showed that there is a negative relationship between preparation and adjustment to retirement for civil servants in Enugu State. This implies that some retirees adjust without adequate preparation while some prepare and could not adjust properly.

Table 4: Mean and standard deviation scores for gender influence on preparation for retirement

\begin{tabular}{|l|l|l|l|l|l|l|l|l|}
\hline Items & Male & & & & Female & & & \\
\hline Variables & No 267 & Mean & SD & Decision & No 64 & Mean & SD & Decision \\
\hline $\begin{array}{l}\text { Bought } \\
\text { shares }\end{array}$ & & 1.79 & & Low & & 2.1 & & Low \\
\hline $\begin{array}{l}\text { Bought } \\
\text { bonds }\end{array}$ & & 1.44 & & Low & & 1.31 & & Low \\
\hline Trained & & 2.95 & & High & & 2.83 & & High \\
\hline
\end{tabular}


Effects Of Gender Pre-Retirement Preparation And Adjustment In Retirement: A Case Study Of

\begin{tabular}{|c|c|c|c|c|}
\hline $\begin{array}{l}\text { your } \\
\text { children }\end{array}$ & & & & \\
\hline Built houses & 1.39 & Low & 2.11 & Low \\
\hline $\begin{array}{l}\text { Learnt some } \\
\text { skills }\end{array}$ & 2.00 & Low & 2.18 & Low \\
\hline $\begin{array}{l}\text { Saved } \\
\text { enough } \\
\text { money }\end{array}$ & 1.82 & Low & 2.34 & Low \\
\hline $\begin{array}{l}\text { Maintained } \\
\text { some private } \\
\text { business } \\
\text { ventures }\end{array}$ & 1.69 & Low & 1.19 & Low \\
\hline $\begin{array}{l}\text { Secured a } \\
\text { large area of } \\
\text { land for } \\
\text { farming }\end{array}$ & 2.28 & Low & 2.31 & Low \\
\hline $\begin{array}{l}\text { Went to the } \\
\text { counselor } \\
\text { for training }\end{array}$ & 1.45 & Low & 1.57 & Low \\
\hline $\begin{array}{l}\text { Attended } \\
\text { seminar and } \\
\text { conferences }\end{array}$ & 1.88 & Low & 1.87 & Low \\
\hline $\begin{array}{l}\text { Read up so } \\
\text { many books } \\
\text { about } \\
\text { retirement }\end{array}$ & 1.84 & Low & 1.80 & Low \\
\hline $\begin{array}{l}\text { Attended } \\
\text { workshops } \\
\text { on } \\
\text { retirement }\end{array}$ & 1.70 & Low & 1.65 & Low \\
\hline $\begin{array}{l}\text { Participated } \\
\text { in some } \\
\text { training }\end{array}$ & 1.77 & Low & 1.95 & Low \\
\hline $\begin{array}{l}\text { Felt the } \\
\text { government } \\
\text { will take } \\
\text { care of you }\end{array}$ & 2.86 & High & 2.71 & Low \\
\hline $\begin{array}{l}\text { Felt your } \\
\text { pension will } \\
\text { take care of } \\
\text { your } \\
\text { financial } \\
\text { needs }\end{array}$ & 2.70 & high & 2.52 & High \\
\hline $\begin{array}{l}\text { Felt your } \\
\text { children will } \\
\text { take care of } \\
\text { you }\end{array}$ & 2.75 & High & 2.63 & High \\
\hline $\begin{array}{l}\text { Felt your } \\
\text { spouse will } \\
\text { take care of } \\
\text { you }\end{array}$ & 2.09 & Low & 2.14 & Low \\
\hline $\begin{array}{l}\text { Did some } \\
\text { voluntary } \\
\text { work }\end{array}$ & 2.27 & Low & 2.18 & Low \\
\hline $\begin{array}{l}\text { Maintained } \\
\text { good } \\
\text { relation with } \\
\text { friends }\end{array}$ & 3.16 & High & 2.93 & High \\
\hline $\begin{array}{l}\text { Engaged } \\
\text { yourself in a } \\
\text { lot of social } \\
\text { work }\end{array}$ & 2.31 & Low & 2.41 & Low \\
\hline $\begin{array}{l}\text { Trained } \\
\text { yourself } \\
\text { against } \\
\text { competition }\end{array}$ & 2.18 & Low & 2.20 & Low \\
\hline $\begin{array}{l}\text { Trained } \\
\text { yourself to } \\
\text { help others }\end{array}$ & 2.80 & High & 2.74 & High \\
\hline $\begin{array}{l}\text { Felt you will } \\
\text { lose your } \\
\text { prestige }\end{array}$ & 1.88 & Low & 2.11 & Low \\
\hline
\end{tabular}




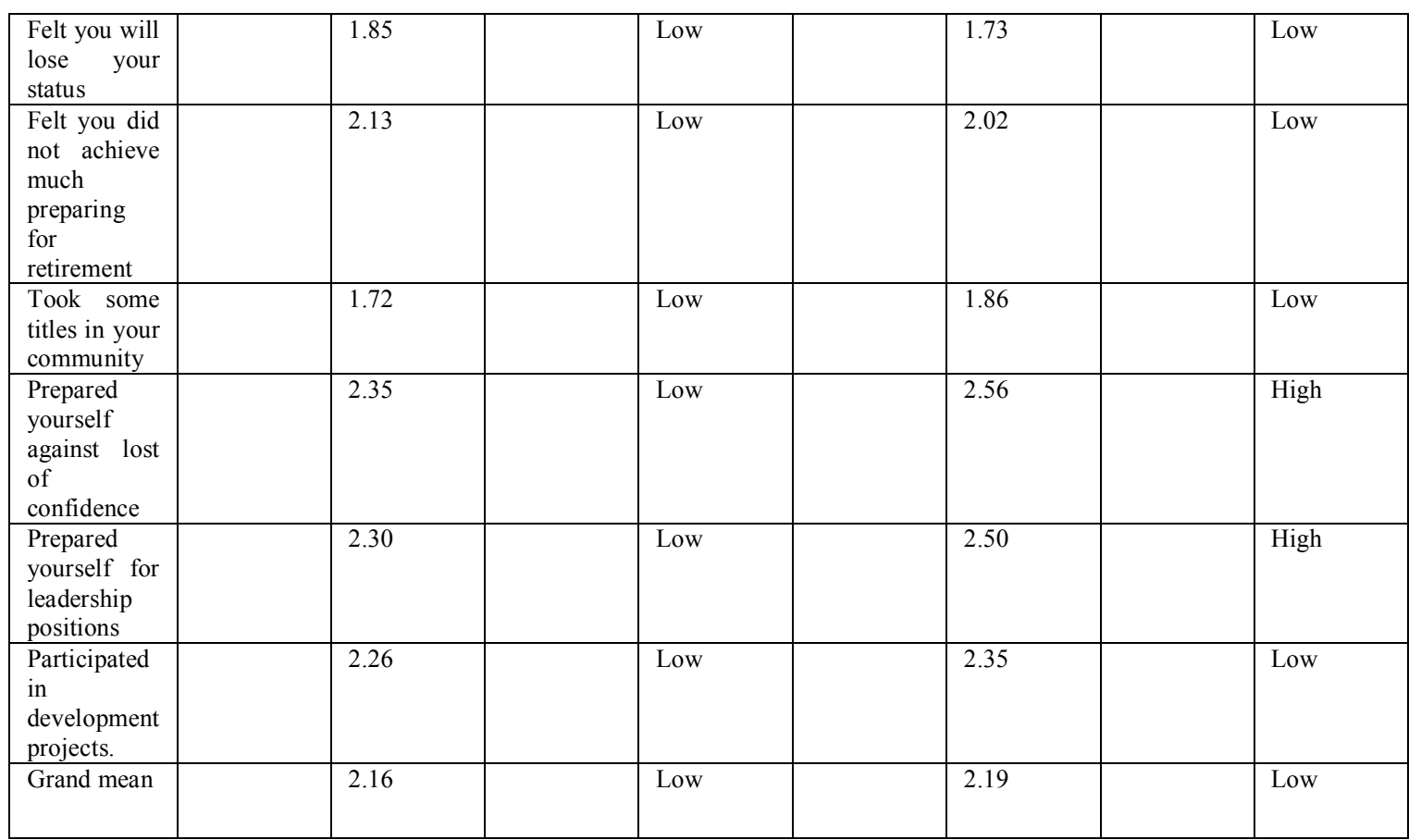

Judging from the table above there is no serious gender difference in preparation for retirement. The grand mean for males is 2.16, while for females it is 2.19. Both scores are below the 2.5 acceptance level and thus showed that both males and female retirees in Enugu state are not prepared for retirement. The little difference in preparation for retirement for both sexes is in items 27 and 28 for females with the scores of 2.56 and 2.50 respectively. The females showed that they prepared themselves against lost of confidence and as well prepared for leadership positions when compared with their male counterparts who scored 2.35 and 2.30 respectively in the same items.

Table 5: Mean standard deviation scores for gender influence on adjustment to retirement.

\begin{tabular}{|c|c|c|c|c|c|c|c|c|c|}
\hline & & Male & & & & Female & & & \\
\hline & Variable & No 267 & Mean & SD & Decision & No 64 & Mean & SD & Decision \\
\hline & Item & & & & & & & & \\
\hline 1 & $\begin{array}{l}\text { I feel } \\
\text { disturbed } \\
\text { that I cannot } \\
\text { meet up with } \\
\text { my financial } \\
\text { obligations } \\
\text { (now in } \\
\text { retirement }\end{array}$ & & 2.4 & & Low & & 2.4 & & Low \\
\hline 2 & $\begin{array}{l}\text { I regret my } \\
\text { condition } \\
\text { now because } \\
\text { I feel I did } \\
\text { not prepare } \\
\text { well } \\
\text { financially. }\end{array}$ & & 2.1 & & Low & & 2.1 & & Low \\
\hline 3 & $\begin{array}{l}\text { My } \\
\text { complaint in } \\
\text { retirement is } \\
\text { non payment } \\
\text { retirement } \\
\text { benefits }\end{array}$ & & 2.6 & & High & & 2.33 & & Low \\
\hline 4 & $\begin{array}{l}\text { I regret my } \\
\text { financial } \\
\text { abandonment } \\
\text { by members } \\
\text { of my family }\end{array}$ & & 1.8 & & Low & & 1.6 & & Low \\
\hline 5 & $\begin{array}{l}\text { You do not } \\
\text { seem } \\
\text { stressed up }\end{array}$ & & 2.1 & & Low & & 2.0 & & Low \\
\hline 6 & $\begin{array}{l}\text { Your health } \\
\text { condition is }\end{array}$ & & 2.1 & & Low & & 2.2 & & Low \\
\hline
\end{tabular}




\begin{tabular}{|c|c|c|c|c|c|}
\hline & $\begin{array}{l}\text { not worse } \\
\text { than what it } \\
\text { used to be. }\end{array}$ & & & & \\
\hline 7 & $\begin{array}{l}\text { You felt the } \\
\text { changing of } \\
\text { your place } \\
\text { residence } \\
\text { during } \\
\text { retirement. }\end{array}$ & 2.1 & Low & 2.1 & Low \\
\hline 8 & $\begin{array}{l}\text { It is difficult } \\
\text { for me to } \\
\text { adjust in } \\
\text { retirement }\end{array}$ & 2.2 & Low & 1.97 & Low \\
\hline 9 & $\begin{array}{l}\text { To what } \\
\text { extent are } \\
\text { you } \\
\text { surprised the } \\
\text { shabby way } \\
\text { you are } \\
\text { retired and } \\
\text { treated. }\end{array}$ & 2.6 & High & 2.36 & Low \\
\hline 10 & $\begin{array}{l}\text { You are } \\
\text { satisfied with } \\
\text { your life } \\
\text { expectations } \\
\text { that you felt } \\
\text { you prepared } \\
\text { well for retir } \\
\text { ement and } \\
\text { you are } \\
\text { enjoying the } \\
\text { fruit of your } \\
\text { labour. }\end{array}$ & 2.84 & High & 2.88 & High \\
\hline 11 & $\begin{array}{l}\text { The present } \\
\text { level of } \\
\text { relationship } \\
\text { with other } \\
\text { members of } \\
\text { your family } \\
\text { is cordial. }\end{array}$ & 2.9 & High & 3.06 & High \\
\hline 12 & $\begin{array}{l}\text { Lack of care } \\
\text { by the } \\
\text { society }\end{array}$ & 1.98 & Low & 2.01 & Low \\
\hline 13 & $\begin{array}{l}\text { That I do not } \\
\text { adapt easily } \\
\text { and quickly } \\
\text { to changes. }\end{array}$ & 2.04 & Low & 2.0 & Low \\
\hline 14 & $\begin{array}{l}\text { That I do } \\
\text { more discuss } \\
\text { issues gently } \\
\text { and politely. }\end{array}$ & 1.87 & Low & 1.8 & Low \\
\hline 15 & $\begin{array}{l}\text { Poor social } \\
\text { condition }\end{array}$ & 1.99 & Low & 1.8 & Low \\
\hline 16 & $\begin{array}{l}\text { Lack of care } \\
\text { by the } \\
\text { government }\end{array}$ & 3.10 & High & 2.37 & Low \\
\hline & Grand mean & 2.29 & & 2.19 & Low \\
\hline
\end{tabular}

Table 5 above, show that males and females have a grand mean of 2.09 and 2.19 respectively. Although they are slightly different, it falls below the acceptance level of 2.50 and above. This shows that both males and females in this study are adjusted in retirement. The major difference in the adjustment for both males and females in this study is that males in item 16 perceived lack of care by government with 3.10 while females had 2.37 below the acceptance level. However from the point of the categories of this instrument; financial, psychological and social, males showed in items 3, 9 and 10 that they are more maladjusted since they complained more of nonpayment of retirement benefits and are as well surprised the way they were retired and treated. Inversely, both male and female do not feel disturbed that they cannot meet up with their financial obligation. As well, they do not regret their condition now because they feel they did not prepare themselves well financially. 
Table 6: $t$-test of significance of $R$ represented in the correlation matrix and adjustment to retirement.

\begin{tabular}{|l|l|l|l|l|l|l|}
\hline Variables & Mean & SD & Df & $\begin{array}{l}\text { Calculated t- } \\
\text { value }\end{array}$ & critical & Decision \\
\hline Preparatory scale & 2.03 & 0.4940 & 229 & -0.050 & 1.96 & Retained \\
\hline Adjustment scale & 2.20 & 0.5709 & & & & \\
\hline
\end{tabular}

This result show that the correlation coefficient for preparatory for retirement and adjustment to retirement $\mathrm{R}=$ $0.050(1.96>-0.050)$ is significant at 0.05 level of significance and 331 degree of freedom. Thus the null hypothesis is accepted implying that preparation for retirement is not significantly related to adjustment although inversely. This agrees with research question three that there is no relationship between preparation and adjustment to retirement.

Table 7: Summary of t-test analysis on preparation due gender.

\begin{tabular}{|l|l|l|l|l|l|l|l|}
\hline Variables & No & Mean & SD & Df & $\begin{array}{l}\text { Calculated t- } \\
\text { value }\end{array}$ & t-critical & Decision \\
\hline Males & 267 & 2.26 & 0.4857 & 229 & 0.587 & 1.96 \\
\hline Females & 64 & 2.19 & 0.5300 & & & & Retained \\
\hline & & & & & & & \\
\hline
\end{tabular}

The table above presents the t-test analysis of the difference between male and female respondents on preparation for retirement. The table show that the calculated t-value is $0.587<1.96$ at 331 degree of freedom and 0.05 level of significance. Since the calculated t-value is less than the table value of 1.96 , the second null hypothesis is thereby retained. There is therefore no significant difference in preparation to retirement for males and female retirees in Enugu State.

Table 8: Summary of t-test analysis of retirees' post-retirement adjustment due to gender.

\begin{tabular}{|l|l|l|l|l|l|l|l|}
\hline Variables & No & Mean & SD & Df & Calculated & t-critical & Decision \\
\hline Males & 267 & 2.29 & 0.5962 & 229 & 0.767 & 1.96 & Retained \\
\hline Females & 64 & 2.19 & 0.5345 & & & & \\
\hline
\end{tabular}

This table shows the analysis of the difference between males and female respondents on adjustment to retirement. From the table, it is observed that the calculated t-value is 0.767 at 331 degree of freedom and 0.50 level of significant. Since the calculated value is $(0.767<1.96)$ less than the table value of 1.96 , the third null hypothesis is accepted. There is therefore no significant difference in the adjustment of males and females retirees.

\section{SUMMARY \\ OF \\ FINDINGS}

The findings in this study are summarized as follows; 1)the extent of preparation for retirement is low with a mean score of 2.03, that is to say that retired civil servants in Enugu State did not prepare well for retirement, 2)The extent of adjustment of civil servant in Enugu State towards retirement is low with a score of 2.20, this shows that the retirees did not adjust well to retirement. 3) There is a high negative relationship between preparation and adjustment to retirement. There was poor preparation for retirement by civil servants in Enugu State, so there is poor adjustment to retirement. 4) There is no gender difference in preparation and adjustment to retirement by retired civil servants in Enugu State.

\section{Discussions}

The findings in research question one tend to agree with the opinion expressed by Horwitz (1968) that retirement shock is the new sickness of the aged. Because far too few elderly people are prepared, either through choice or through condition beyond their control, retirement shock is becoming one of the major problems of the elderly today. Experience shows that most established workers do not give thought to or attention to retirement. To most workers it is an event that happen to other people. The lucky ones are eased out on attainment of mandatory retirement age. To others it comes like a thunderbolt, they either hear about it over the radio or read it in a newspapers. Anieke (2001) "to live a successful or trouble free retirement life is to plan for it now. The sooner you started to invest in your retirement, the longer your contribution and potential growth". This tends to portray that preparation and effective planning is paramount to a better adjusted retirement. That adjustment in retirement is dependent on preparation for retirement, that is to say, no proper planning and preparation, no proper adjustment in retirement.

The findings in research question two is not far from expectation because, Brown (1988), stated that "old people are typically faced with feelings of isolation, meaninglessness ,in life, feeling unproductive, unneeded and unwanted by the society, feeling of despair, fear of death and dying, sadness over physical and mental deterioration, depression and regrets over past events". One major fact in retirement is the apprehension of the effects of countdown to end of biological life on earth, which aggravates emotional disturbances. The problem of life in retirement could be discouraging to people approaching retirement in Nigeria. The deplorable 
sight of retirees in various degrees of deteriorated health and physical conditions, queuing up for days at subtreasuries to collect their monthly pensions is disheartening. The result show that when workers are owed their salaries and allowances during the time of work, they cannot adjust or fit into the society because there will be a significant decrease in purchasing power as compared to the pre-retirement purchasing power. The focus of this research is 'the influence/effect of gender in pre-retirement preparation and adjustment in retirement', the findings in this study show that is slight difference. The difference is not much in preparation. Although it is widely viewed that due to male dominance of the entire work force, family and society, that males will be better prepared for retirement when compared with females, the findings of this study portrayed otherwise, both males and females are not prepared. This goes to suggest that there may be factors or variable that may warrant preparation, poor or lack of preparation, which is not gender suggestive. On adjustment to retirement Baron (1961) emphasized that woman as a whole adjusts more easily to retirement than men. The role change is not as radical for them as for men because they have played the domestic role, whether they are married or single through their working lives, in addition to their work. Furthermore, they get greater psychological satisfaction from homemaking, friendship and club activities than men do. Men, on the other hand have less readily available means of securing satisfaction to replace their work and as a result, adjust less to the role change necessitated by retirement. The fact that women play secondary role in our society gives credence to their adjustment. Women have less to worry about in terms of finance when the men are there as the breadwinner. Women feel secured as far as the husband is around in terms of social protection. Women feel satisfied if they have trained and established children. It is a puzzle to the researcher that women in this study are not far and wide better adjusted than their men counterparts.

\section{Recommendations}

That if whatever has a beginning must have an end, people who prepared for the beginning (entrance into a job) should as well prepare for the end of work (retirement). That retirement preparation should be paramount in any workers mind. Most important is that no person will prepare for you but you. .That retiring civil servants should endeavor to prepare a retirement (budget) and implement it with a degree of seriousness, for "a stitch in time saves nine". This is in addition to the Igbo adage that says "Nku onye kpatalu na okochi ka ona anya na udumili" (the fire wood collected during the dry season that one uses during the rainy season).

That government should enact policies and laws covering retirement where retirees are exposed to school and training for retirement.

Counselors in Nigeria should move out of the classroom to assist needy retirees on personal social adjustment. Counselors should redirect their attention to shift from classroom to the streets and community where they are needed by multitude of confused retirees.

\section{References}

[1]. O.O. Abdulrazag, (1999) Sex Difference in Problems of Retired Civil Servants and the Roles of Counseling in Rehabilitation of Retirees. The Counsellor Vol.17 No 1. P.56

[2]. N. Igwebueze, (1988),in Achigbe (1998). The Effect of Lack of Retirement Plan on Self Reliance and Desire for Work Among Retired Civil Servants of Cross River State Public Service. The Counsellor Vol.17 No 79.

[3]. S. Gee, (2002),Saving Ourselves: Gender Issue in Making Provision for One's Own Retirement. Australian Journal on Aging

[4]. R.C. Anieke, (2001). Getting Ready for Retirement. Enugu: Snaap Press Ltd

[5]. A.O. Abudu, (1999), How to Prepare for a Comfortable Retirement. Ghana. Dyno-Media Ltd

[6]. E.B. Hurlock (1968), Developmental Psychology. New Delhi Tata Mcbraw-Hill Pub. Co

[7]. M.L. Baron (1961), The Aging American: An Introduction to Social Gerontology and Geriatrics. New York. Cramwell

[8]. E.C Giouoeua,. and Bevil, C.W. (1985) .Nursing Care of Aging Client. Conecticut, Appleto-Centicy Croft

[9]. A.A Olagboye,. (1998), Joys and Agonies of Retirement and Job loss. Lagos Joja Educational Research and Publishers Ltd.

[10]. E.C Osuala. (1985), Retirement Counseling is Necessary. Nigerian Statesman April 5, p.9

[11]. P.A Uzoma,. (1997, Actuarial Valuation of Pension Fund. A Paper Presented in a Workshop on the Management of Pension Schemes of Parastatals and other Organizations Funded by the Federal Government of Nigeria 